\title{
Power and Conflict in Russia's Borderlands. The Post-Soviet Geopolitics of Dispute Resolution
}

\author{
Helena Rytövuori-Apunen \\ London: I.B. Taurus 2019 \\ 344 sidor. ISBN 9781788311434
}

Recenserad av Claes Levinsson [forskare och prefekt, Institutet för Rysslands- och Eurasienstudier (IRES), Uppsala universitet, claes.levinsson@ires.uu.se]

I slutet av 1991 fanns det cirka 170 etno-territoriella tvister i före detta Sovjetunionen och 73 av dem rörde direkt Ryssland. Dessa var konflikter som uppstod när länge undertryckta etniska motsättningar blossade upp i samband med Sovjetunionens kollaps. Även om flera av dessa konflikter genom åren har blivit lösta har många fortsatt att plåga Ryssland sedan dess. En typ av territoriella konflikter som uppstod i början av 1990-talet var öppna väpnade konflikter som sedan aldrig blev bilagda. De blev frysta. Det är konflikter som kännetecknas av stor osäkerhet och instabilitet och kan när som helst ta fart igen. Ryssland har ända sedan dessa startade varit den primära aktören i dessa tvisters konflikthantering. Idag ser vi kanske begynnelsen av fler av den här typen av frysta konflikter efter Rysslands annektering av Krim och den ryska inblandningen i den pågående väpnade konflikten i Donbas-området. Det här är också konflikter som systematiskt utnyttjas av den ryska regeringen för att behålla inflytandet över grannländerna i det postsovjetiska området.

Vi analyserar dessa konflikter oftast med traditionella säkerhetspolitiska analysverktyg alternativt genom geopolitiska eller ny-imperialistiska förklaringsmodeller ofta med referenser till kalla kriget. Ett annat vanligt förklaringsraster ser den ryska utrikes- och säkerhetspolitiken som ett resultat av en intern kamp mellan "atlanticism» och "derzjavniki», eller att det ryska agerandet i det postsovjetiska området kopplas samman med konflikten mellan Ryssland och det NATO-dominerande väst och då ofta analyseras utifrån spelteoretiska perspektiv med förutsägbara reaktionsmönster. Det är många gånger en alltför förenklad och deterministisk analys som inte alltid tar hänsyn till den djupare historiska och kulturella kontexten.

I Helena Rytövuori-Apunens utomordentligt välskrivna bok görs en omfattande genomgång av de frysta konflikterna i Sydossetien och Abchazien, Transnistrien och Gagauzien samt Nagorno-Karabach. Boken vägleder oss på ett övertygande sätt in i 
en djupare förståelse av dessa konflikters uppkomst, förlopp och Rysslands inblandning. Detta analyseras genom tre centrala begrepp, djupa gränser (deep borders), vertikal makt och det internationella samfundet. Forskningsfrågan är hur ryska djupa gränser skapas, konsolideras och avgränsas. Det här kopplas till hur Rysslands konflikthantering i de här regionerna samspelar med linjära statsgränser, internationella förhållanden och den specifikt ryska politiska maktvertikalen. Medan de två sistnämnda begreppen utgår från de strategiska interaktioner som sker i konfliktområdena och internationellt, är begreppet "djupa gränser» något som rör kontinuitet och legitimitet. Det är i samspelet mellan dessa tre begrepp som ett mönster uppstår och som i boken benämns pragma. Detta sorts mönster, eller pragma, uppkommer genom relationer, rutiner och praktiker som befästs i både tid och rum.

Bokens stora bidrag till analysen av dessa segdragna frysta konflikter är problematiseringen av begreppet "djupa gränser». Det är genom detta som RytövuoriApunens konfliktanalys lyckas tränga djupare ned i de förhållanden som utgör de centrala strukturer som påverkar aktörernas handlanden och tvisternas dynamik. Det är en grundligare och mer genomträngande analys än vad mycket annan gängse forskning gör. Djupa gränser kan handla om säkerhetspolitiska strategiska överväganden, ekonomiska resurser, kulturellt och ideologiskt inflytande, och detta kan manifesteras genom symboliska markörer som flaggor, ett gemensamt språk och större fysiska strukturer, till exempel militära baser. Gränserna blir »djupa» när de gör det möjligt för en stat att etablera närvaro i ett specifikt område på en annan stats territorium. Denna närvaro konsolideras med argumentet att det finns legitima skäl att påta sig ett särskilt ansvar, eller tillsyn, över de delar av befolkningen som den har en etnisk koppling till eller på grund av långa historiska relationer. Genom detta rättfärdigar den inkräktande staten sin närvaro på en annan stats territorium. Ofta har den här situationen uppstått som ett resultat av territoriella och demografiska förändringar som inträffade under den sovjetiska perioden. Gränsen "fördjupas» genom att närvaron uppfattas som något positivt i det aktuella området, vilket bekräftar en föreställning om att båda parter är samstämmiga. På detta sätt motiverar och legitimerar Ryssland sin närvaro och inblandning i dessa regioner, även om det står i strid med internationell rätt eller i ett direkt motsatsförhållande till annan stats territoriella anspråk.

En viktig observation är att den temporala dimensionen förefaller vara överordnad den rumsliga i det postsovjetiska området, det vill säga på det sätt som den påverkar politiska maktförhållanden eller sociala relationer. De nya territoriella konfigurationer som uppstod i kölvattnet av Sovjetunionens upplösning och den efterföljande statsbyggnadsprocessen baserades ofta på en traditionell, statisk och pre-nationell uppfattning om territorium och samhälle. Den rumsliga dimensionen var begränsad medan den temporala, definierad av historia och myt, gick tillbaka till ett avlägset förflutet och uppfattades ofta som något sorts evigt. Idag kan vi se att den rumsliga dimensionen ofta uttrycks genom olika försök till politisk och/eller ekonomisk integration i regionala eller internationella sammanhang. När det rumsliga 
möter det temporala skapar det ofta spänningar, och kanske till och med nya stridslinjer, både inom och mellan stater. Dagens konflikt mellan Ryssland och Ukraina är här ett bra exempel.

Vill vi förstå dynamiken i att vissa konflikter blir frysta, och varför en lösning ofta är så svår att nå, måste vi således gå bortom föreställningen att dessa enbart kan analyseras utifrån instrumentella säkerhetspolitiska intressen och maktprojicering. Det handlar i lika hög grad om intersubjektiva föreställningar av att platsen och området är kopplat till en territoriell identitet som bygger på en upplevd historisk kontinuitet och legitimitet. Territoriet är alltså inte bara en manifestation av statsmakt utan också ett påtagligt bevis som berättar om invånarnas förflutna, nutid och framtid. Det är en territoriell identitet som objektifierar en uppfattning om etnicitet, språk och kulturell homogenitet bland invånarna i staten och regionen, och det är det här som ofta skapar konflikt, inte bara inom stater utan också bland stater. Det kan då ses som en dragkamp mellan det rumsliga och det temporala. Om vi vill göra en grundlig analys av varför vissa konflikter blir frysta och om vi strävar efter att försöka förstå båda sidors ofta oförenliga krav är detta därför centrala komponenter som måste utredas.

Sammanfattningsvis har Helena Rytövuori-Apunen skrivit en bok som ger läsaren ett användbart verktyg för att på djupet förstå och analysera några av det postsovjetiska områdets mest segdragna konflikter. För alla som är intresserade av territoriella konflikter och rysk konflikthantering är den här boken en obligatorisk läsning. 